\title{
Unused Goods: Science Learning Through Reggio Emilia Approach
}

\author{
Lilis Madyawati ${ }^{1}$, Dwi Prihati ${ }^{2}$, Syakilla Fathia Rizki $^{3}$ \\ \{1ilis_madya@ummgl.ac.id $\left.{ }^{1}\right\}$ \\ PG PAUD, Universitas Muhammadiyah Magelang, 56126, Indonesia ${ }^{1,3}$ \\ Universitas Muhammadiyah Magelang, 56126, Indonesia ${ }^{2}$
}

\begin{abstract}
The low achievement of science in children should not be ignored. One of the efforts to improve the children's science achievement is by conducting science learning through Reggio Emilia Approach with unused and recycled goods. This study aims at depicting the implementation of Reggio Emilia Approach in science learning at a kindergarten in Central Java. The instruments of this study were interview guide, observation sheet, and documentation technique. Validity and reliability test were conducted for the instruments. Descriptive qualitative was the data analysis method. The result showed that unused goods help the children develop their creativity and environmental care from an early age. However, in the teaching and learning process, the collaboration among the teachers is less optimal. In addition to that, parents need to fully support the learning process and collaborate with the teachers. In conclusion, Reggio Emilia is good for science learning but it needs some improvement in its implementation.
\end{abstract}

Keywords: Unused goods, science learning, reggio emilia

\section{Introduction}

Every child deserves education according to their developmental phases and needs. Since childhood is a phase of playing, the learning should be as fun as playing. 'Learning while playing' should be implemented for the children. Science is one of subject to teach for the children. By considering the children's phase, the process of science learning must seem playing for them. Children usually like to observe and think about their surroundings. During this observation, the science learning can be instilled to the children. The introduction of scientific phenomena and its benefits from an early age results in a better understanding of scientific concepts. As a series of concepts and conceptual schemes, science is a series of experiments and observations that can be examined further. It is also closely related to the tracing of natural phenomena which is undergone through experiment and prediction. For early childhood, science is helpful to develop their critical thinking.

Science has various values of children's development, including cognitive skill, affective skill, psychomotor, thinking skill and creativity, actualization and readiness for life, and religious development. So far, science learning is rarely provided for early childhood. Teachers often feel it difficult to teach science for children. The existing science learning, however, is usually still monotonous and less attractive and uses less real, easy-to-find, and self-made media. It causes less creativity of the children, which is proven in form of works made by the 
children that are usually similar from one activity to another. Furthermore, children tend to imitate their friends' work and have a limited understanding of scientific activities.

The afore-mentioned situation indicates the low achievement of science in children. This low achievement, however, should not be ignored. There are many efforts to optimize the science skill of children. Marliza [1] conducted research on improving the science skill of children through plant learning. In addition to this effort, another one was made by Roza [2] in Aisyiyah Kindergarten 29. His study reveals that the barrier to science learning is the lack of creativity of the teachers in designing the science activities. Akerblom [3] in his research entitled 'Children's Understanding of Representations of Basic Chemistry', Concluded that science learning affects the children's activities. Another research entitled 'Attitude toward informal science in the Early Years and Development of Leisure Time in Science', which is conducted by Panos \& Gallarelo [4], proved that there is a relationship between attitude and real activities during scientific activities.

Research on science learning through the Reggio Emilia Approach in early childhood is still rarely conducted. This current study examines the implementation of Reggio Emilia Approach. This research has the potential to: a) foster children's love for knowledge, b) cultivate the children to be critical thinkers and scientific researchers who have high curiosity, c) support the children's ideas and creativity. By doing this research, we expect that the children are able to: a) create their own learning process, b) develop their cognitive skills, c) learn how to communicate and make relationships with peers, teachers, and parents.

This study achieves success in conducting science learning through the Reggio Emilia Approach. The media and materials used in this study are unused goods at home and at school. By doing this, it helps the children to develop their creativity and environmental care from an early age.

\section{Method}

This research was approached qualitatively where we proposed the solution of the problem in conducting science learning by suggesting the use of unused goods. Following the proposal of the activities to conduct, we examined the implementation of Reggio Emilia Approach by using the unused goods media. Subject of the research was class B of a Private Kindergarten in Magelang consisting of 37 students, 3 teachers and the headmaster. The detail of the implementation of teaching and learning process is explained below.

\subsection{Setting of the class}

Teachers should consider the layout and nuance of a class employing Reggio Emilia Approach. The class setting aims at creating a cozy and relaxing class. The environment is one of the important aspects of teaching and learning process.

\subsection{Tools and Materials (ateliers)}

Ateliers (tools and materials) consist of: White and dark chocolate, unused stamp pad, food coloring, soap, unused bottles, straws, clamshells, seeds, stones, unused ribbon, cotton, patchwork, sugar, vinegar, and spices. 
2.3 The procedure of the science teaching and learning process must follow certain rules we described in the proposal

Table 1 present list of ateliers used and activities that can be conducted using those ateliers in science learning for children.

Table 1. Ateliers and activities

\begin{tabular}{|c|c|}
\hline Atelier & Activity \\
\hline Chocolate & Proses of melting \\
\hline Unused stamp pad & Drawing flowers \\
\hline Food coloring & \\
\hline Soap & Making foam and bubble \\
\hline Unused bottles, straws & \\
\hline Clamshells & Letters, numbers \\
\hline Seeds, stones & Pattern \\
\hline Unused ribbon & Long-short concept, forming \\
\hline Cotton, patchwork & Smooth-rough concept, forming \\
\hline Sugar, vinegar, spices & Sniffing, taste \\
\hline
\end{tabular}

During the observation, however, other than the activities shown in the table 1, in fact, children acted and innovated based on their interest, ideas, and imagination during the activities. During the implementation of Reggio Emilia Approach, roles of children and teachers must also be determined. Below are the roles of the two.

\section{a. Children's roles}

- Children should be assured that they are competent and able to do many things

- Active student

- Continued creating

- Test himself and his surroundings

\section{b. Teachers' roles}

- Becoming a learner, together with his/her students

- A researcher of activities and student's works.

- Becoming a good listener

- Observer, documenting the activities and students' works, supporting and helping to recreate, stimulating to collaborate with peers.

\section{Results and Discussion}

\subsection{Results}

Teachers have prepared various kinds of ateliers inside and outside the class. Ateliers are in form of unused goods, recycled goods, and things around the children. The result of observation of the implementation of science learning through Reggio Emilia Approach can be seen in the table 2. From table 2, it can be shown that children enjoyed each of the procedures in learning science. On the other hand, parents seem to have lack of involvement in this process. 
Table 2. Observation result of science learning

\begin{tabular}{lll}
\hline No & \multicolumn{1}{c}{$\begin{array}{c}\text { Focus of } \\
\text { observation }\end{array}$} & \multicolumn{1}{c}{ Result of observation } \\
\hline 1 & Teachers & Motivate the children to do the activities \\
& Plan, facilitate, assess the children \\
& Guide the children \\
& Use real-unused things \\
& Document the children's works \\
& Facilitate the children to tell what they have been learned \\
& Seriously and happily observe: \\
& a. Mentos candy is put into a bottle of sprite while the bottle is closed with a \\
& Children & balloon \\
& b. grouping: arranging plastic bottles according to size \\
& c. analyzing: saying that sprite will be spilt \\
& d.predicting: balloon will be wrecked \\
& e. applying: stir a glass of milk using spoon \\
& f. planning research: mix milk with color, stir it using cutton buds \\
& g. communicating: presenting the result of activities \\
& h. organizing the class: invite friends to do the same \\
& There is a lack of direct involvement from parents. Parents provide ateliers, but it \\
& is only occasional.
\end{tabular}

In addition to the science observation of teaching and learning process, we also conducted interviews with teachers. Interview was employed to achieve in-depth data on the teaching and learning process. The following table 3 shows the result of interview with teachers.

Table 3. Interview result with teachers

\begin{tabular}{|c|c|c|}
\hline No & Indicator & Result of observation and interview \\
\hline 1 & Activity plan & Made based on the result of discussion with the children \\
\hline 2 & Conformity of the activity and the plan & $\begin{array}{l}\text { Sometime activities match the plan, but more often develop } \\
\text { according to the children }\end{array}$ \\
\hline 3 & Documentation/assessment & $\begin{array}{l}\text { Making notes, photos, videos of the process of creating } \\
\text { products }\end{array}$ \\
\hline 4 & Activity document & $\begin{array}{l}\text { Made based on the children's activity, guiding children if } \\
\text { necessary }\end{array}$ \\
\hline 5 & Collaboration among teachers & Only for important thing \\
\hline 6 & $\begin{array}{l}\text { Collaboration between teachers and } \\
\text { parents }\end{array}$ & Rarely conducted \\
\hline
\end{tabular}

To gain the trustworthy of the data, we also interviewed the parents. The interview is about their children's learning of science implementation, too. Table 4 sumps up the result of interview with parents.

Table 4. Result of Interview with Parents

\begin{tabular}{llll}
\hline No & \multicolumn{1}{c}{ Indicator } & \multicolumn{1}{c}{ Response } \\
\hline 1 & $\begin{array}{l}\text { Reason related to Reggio } \\
\text { Approach }\end{array}$ & Emilia & $\begin{array}{l}\text { A good and interesting learning approach, children do not feel } \\
\text { bored }\end{array}$ \\
2 & Children's problem in school & No problem, children happily join the activities \\
3 & Parents' contribution & Tuition fees and annual donation \\
4 & Children's guidance at home & Test and try things as they did in school \\
5 & Children's development & Children become more active and creative \\
\hline
\end{tabular}




\subsection{Discussion}

This study reveals that when the children involve in science learning through Reggio Emilia Approach with unused and recycled goods, there is a lack of collaboration among teachers. Tichenor [5] mentioned that the main problem for the teachers in conducting teaching and learning process is facing the class itself. Further, he mentioned that many teachers have less clear teaching strategies and have less expectation to improve the quality of the teaching. Another problem found was that some experienced teachers have difficulty in helping the novice teachers. The main problem in applying science learning through Reggio Emilia Approach is the un-readiness of the teacher to apply the strategy. Another problem is the reluctance of learning new things. Even worse, teachers are unwilling to change the mindset about education [6].

Reggio Emilia Approach also requires the collaboration between teachers and parents. However, in this case, parents have only a bit attention to the science learning through Reggio Emilia Approach. Parents only pay the tuition fees and annual donation. They feel that paying tuition fees is enough as a part of parents' involvement in the teaching and learning process. Long time ago, some parents have ever donated unused bottles and stones, but only once. At school, children experiment and explore many things using the ateliers. Ideally, it must be continued at home with the same ateliers, but unfortunately not [7].

As the consequence, when children try to experiment and construct things at school, it cannot be done at home, especially when parents do not allow the children to use unused, waste, and recycled goods. Hence, in this case, there is a need to equalize the understanding of teaching and learning process between teachers and parents.

\section{Conclusion}

Reggio Emilia Approach is actually a good approach in science teaching and learning for children. Based on the research finding, however, it is known that in the process of science learning through Reggio Emilia Approach, there is a lack of collaboration among teachers. Likewise, there is a lack involvement from parents. Parents need to fully support the teaching and learning process by collaborating with teachers. The collaboration between teachers as well as parents' support needs to be improved.

\section{References}

[1] R. Marliza and D. Eliza, "Peningkatan Keterampilan Proses Sains Melalui Kegiatan Belajar Tanaman di Taman Kanak- kanak ABA Air Bangis," J. Ris. Tindakan Indones., vol. 4, no. 1, pp. 59-63, 2019.

[2] M. M. Roza, "Pelaksanaan Pembelajaran Sains Anak Taman Kanak- kanak Aisyiyah Aisyiyah Bustanul Athfal 29 Padang,” J. Ilm. PG-PAUD FIP UNP. Pesona PAUD, vol. 1, no. 1, pp. 1-11, 2020.

[3] A. Akerblom and N. Pramling, "Children's Understanding of Representation of Basic Chemistry After Participating in an Early Childhood,” J. Early Child. Educ. Res., vol. 9, no. 2, pp. 290-313, 2020.

[4] E. Panos and J. R. R. Gallardo, "Attitude Toward Informal Science in The Early Years and Development of Leisure Time in Science," https://doi.org/10.1002/tea, 2020. 
[5] M. Tichenor and J. Tichenor, "Collaboration in The Elementary School: What Do Teachers Think?," J. Curric. Teach., vol. 8, no. 2, pp. 54-61, 2019.

[6] I. Rissanen and E. Kuusisto, "In Search of a Growth Mindset Pedagogy: A Case Study of One Teacher's Classroom Practices,” J. Teachingand Teach. Educ., vol. 77, no. 1, pp. 204-2013, 2019.

[7] S. Humble and P. Dixon, "The Effects of Schooling, Family and Poverty on Childrená attainment, Potential and Confidence,” Int. J. Educ. Res., vol. 83, pp. 94-106, 2017. 